Plant Tissue Cult. \& Biotech. 29(2): 231-244, 2019 (December)

CBangladesh Assoc. for Plant Tissue Culture \& Biotechnology $\overline{\text { PTC\&B }}$

\title{
Agrobacterium rhizogenes-Mediated Transformation of the Critically Endangered Species, Swertia chirayita
}

\author{
Tapojita Samaddar, Sayantika Sarkar and Sumita Jha* \\ Department of Botany, University of Calcutta, 35 Ballygunge Circular Road, Kolkata-700019, \\ India
}

Key words: Swertia chirayita, Agrobacterium rhizogenes, Hairy root lines, Ri-transformed plants, Swertiamarin

\begin{abstract}
Agrobacterium rhizogenes-mediated genetic transformation for the establishment of root culture lines was developed successfully in the critically endangered medicinal plant Swertia chirayita (Roxb.) H. Karst. The key factor for the successfull development of hairy root culture lines was the use of whole micropropagated plants as excised explants of any type did not show any response following infection with $A$. rhizogenes strains. Maximum root induction frequency $(25 \pm 4.4 \%)$ with 2 - 9 roots per node/intermodal cut site was obtained following infection with $A$. rhizogenes strain LBA9402. Spontaneous regeneration of shoot buds was observed in six 9402-transformed root lines maintained in phytohormone free N/5 basal medium. The shoot buds developed for regenerating whole rooted Ri-transformed plants in phytohormone free basal medium. Integration of rolA, rolB , rolC and rolD genes of TL-DNA was confirmed in Ri-transformed root lines and plants by PCR analysis. Ten fast growing Ri-transformed root lines were screened for production of principal secoiridoids, characteristics of the parent plants. The swertiamerin content varied from 0.042 to $0.207 \%$ in the transformed root lines after 4 weeks of culture in $\mathrm{N} / 5$ basal medium. Ri-transformed plants showed enhanced accumulation of swertiamerin as compared to non-transformed plants of similar age. This is the first report of swertiamerin production in hairy root cultures and transformed plants of S. chirayita thereby providing new avenue for large-scale production of secondary metabolites of $S$. chirayita.
\end{abstract}

\section{Introduction}

The most popular traditional Ayurvedic herb of Gentianaceae family, Swertia chirayita (Roxb.) H. Karst. is indigenous to the temperate regions of the Himalayas. This species holds immense ethno-medicinal significance in Ayurveda, Unani and Siddha as well as

*Author for Correspondence: <sumitajha.cu@gmail.com> ksjbot@caluniv.ac.in>.

DOI: https://doi.org/10.3329/ptcb.v29i2.44512 
in Indian pharmaceutical codex, the British and the American pharmacopeias (Brahmachari et al. 2004). The different parts of the herb and its decoction have been well-reported to treat numerous ailments and show varied pharmacological activities (Samaddar et al. 2014, Zhou et al. 2015, Kumar and Staden 2016). Although the whole plant is found to be useful in traditional remedies, the root is considered to be the most bioactive part (Kirtikar and Basu 1984).

Scientific exploration of chemical constituents of this plant has shown that different classes of bioactive compounds such as iridoids, secoiridoids, xanthones, lignans, alkaloids, flavonoids and terpenoids are responsible for its pharmacological efficacy (Pant et al. 2000). Owing to its high national and international demand in pharmaceutical industries, unscrupulous collection from their natural habitat along with narrow geographic occurrence and problems regarding seed germination have led this plant species to be considered as a critically endangered one according to the new International Union for Conservation of Nature and Natural resources (IUCN) criteria (Joshi and Dhawan 2005). Several studies on micropropagation, somatic embryogenesis and synthetic seed production were conducted for sustainable production of S. chirayita plants throughout the year (Kumar and Staden 2016). Agrobacterium rhizogenes induced hairy root technology has been established in large number of species for the production of secondary metabolites (Halder et. al. 2018). To the best of our knowledge, only one attempt has been made on the establishment of hairy root culture in S. chirayita till date (Keil et al. 2000). In the previous report, root cultures could not be established as true hairy root lines on solid media and amarogentin was reported in roots cultured in liquid medium (Keil et al. 2000).

In spite of several difficulties in collection of this critically endangered species from the wild, hairy root cultures of $S$. chirayita via $A$. rhizogenes mediated genetic transformation was successfully established in the present study. Spontaneous regeneration of Ri-transformed whole plants from hairy roots has been reported for the first time in this species. Analysis of characteristic secondary metabolites i.e. amarogentin, swertiamarin (secoiridoid glycosides) and mangiferin (xanthone) have also been carried out in the present study in Ri-transformed root lines and Ri transformed plants of S. chirayita.

\section{Materials and Methods}

Immature fruits (capsules) of Swertia chirayita were collected from Lava, Darjeeling. For germination, capsules were surface-sterilized with $0.1 \%(\mathrm{w} / \mathrm{N}) \mathrm{HgCl}_{2}$ treatment for $25-30$ min, rinsed 4 - 5 times with sterile distilled water and seeds excised from capsules were placed on MS supplemented with 3\% (w/N) sucrose and $0.75 \%(\mathrm{w} / \mathrm{N})$ agar at $24 \pm 1^{\circ} \mathrm{C}$ and $50-60 \%$ relative humidity in dark. Germinated plantlets were micropropagated by repetitive nodal cultures on MS medium under 16/8 hrs (light/dark) photoperiod with light provided by cool-white fluorescent tubes (Philips, India) at an intensity of 48 $\mu \mathrm{mol} / \mathrm{m}^{2} / \mathrm{s}$. 
Four wild type agropine strains of A. rhizogenes, namely LBA9402 (pRi1855; Hooykaas et al. 1977), A4 (pRiA4; Hooykaas et al. 1977), HRI (pRiHRI; Petit et al. 1983) and R1000 (pRiA4b; Vervliet et al. 1975) were used. For explants infection, a loop-full of bacterium from a single colony was inoculated into $10 \mathrm{ml}$ of liquid bacterial medium viz., for strains LBA9402 and A4, YMB medium (Hooykaas et al. 1977), for strain HRI, AP medium (Petit et al. 1983) and for strain R1000, YEP medium (Vervliet et al. 1975) and incubated on a gyratory shaker (Certomat) at $180 \mathrm{rpm}$ for $20-24 \mathrm{hrs}$ at $26^{\circ} \mathrm{C}$ in dark. 200 $\mu \mathrm{M}$ acetosyringone (Sigma) was added to the overnight grown bacterial suspension $\left(\sim 10^{10}\right.$ cells $\left./ \mathrm{ml}\right) 2 \mathrm{hrs}$ prior to infection to improve virulence.

To study the effects of different strains on rhizogenic response, excised leaf petiole $(\sim 2 \mathrm{~cm})$, excised leaf lamina $(\sim 1.5 \mathrm{~cm})$ and whole plants $(3-4 \mathrm{~cm})$ from three-months old in vitro cultures of $S$. chirayita were used as explants. The explants were wounded with bacterial suspension by a sterile hypodermic needle. In case of whole plants, node/internode (nodes and internodes were not considered separately due to very short internodes), petiole and leaf lamina regions were wounded. Explants wounded with bacteria-free liquid bacterial medium were used as control. In case of excised leaf petiole and leaf lamina segments, both infected and control explants were co-cultivated on a sterile filter paper moistened with liquid MS and kept in dark at $24 \pm 1^{\circ} \mathrm{C}$. After $72 \mathrm{hrs,}$ explants were washed thoroughly with sterile double-distilled water containing $1 \mathrm{~g} /$ ampicillin for $30 \mathrm{~min}$, rinsed 4 - 5 times in sterile double-distilled water and were finally cultured on MS augmented with ampicillin (500 mg $\Lambda$ ) at $24 \pm 1^{\circ} \mathrm{C}$ in dark and $50-60 \%$ relative humidity. In case of whole plants, both infected and control shoots were cultured on MS directly after wounding in culture tubes under $16 / 8 \mathrm{hrs}$ (light/dark) photoperiod at $24 \pm 1^{\circ} \mathrm{C}$ and $50-60 \%$ relative humidity. For each experiment, 50 explants of each type were infected and the experiment was repeated three times.

For establishment of Ri-transformed root cultures, roots induced at wound sites were excised and cultured on MS basal, modified MS basal (N/5; Tepfer 1995) and Gamborg's B5 (Gamborg et al. 1968) basal media in dark condition for 4 weeks under ampicillin (500 $\mathrm{mg}$ 1) selection pressure. Each excised primary root was propagated as a separate clone. Each root line was screened for residual bacterial contamination by culturing root segments in respective liquid bacterial medium. Fast-growing axenic Ri-transformed root lines were maintained on ampicillin-free medium after 12 months with regular subculturing at 4 weeks interval.

To study the morphology and growth of Ri-transformed root lines, root segments $(\sim 3$ $-4 \mathrm{~cm}$ ) were cultured on $\mathrm{N} / 5$ medium in dark at $24 \pm 1^{\circ} \mathrm{C}$. After 4 weeks, roots were harvested and the number of lateral branches on the primary roots (expressed as lateral root density) was recorded. The roots were then washed with de-ionized water, blotted to dry, fresh weight (FW) was measured and growth index (GI) was determined. For each root line, three replicates were used and the experiment was repeated thrice. Shoots regenerating spontaneously from transformed roots were cultured on MS basal medium 
under $16 / 8 \mathrm{hrs}$ (light/dark) photoperiod after 4 weeks of initiation to establish transformed shoot cultures. For each root line, five Petri dishes were used.

Transformation was confirmed by PCR detection of rolA, rolB, rolC and rolD genes of $\mathrm{T}_{\mathrm{L}}$-DNA using genomic DNA and gene specific primers as described for other species (Ray et al. 2014, Roychowdhury et al. 2015). Genomic DNA was isolated from 13 putatively Ri-transformed root lines and 6 regenerated Ri-transformed plant lines after 12 months of maintenance in vitro. The plasmid pLJ1 was isolated following standard alkaline lysis protocol (Sambrook and Russel 2001) and was used as a positive control. Genomic DNA from roots and leaves excised from in vitro grown non-transformed plants was used as a negative control. To eliminate the chances of false positive PCR products due to bacterial contamination, virD1 specific primers were used (Alpizar et al. 2008).

Swertiamarin, amarogentin and mangiferin contents were analyzed in 4 weeks old axenic Ri-transformed root lines and Ri-transformed plant lines by HPTLC following the method published earlier (Samaddar et al. 2013). A $500 \mathrm{mg}$ amount of dried sample was taken into the $50 \mathrm{ml}$ conical flask, defatted with $20 \mathrm{ml} \mathrm{n}$-Hexane for $48 \mathrm{hrs}$. The residue was subsequently extracted with $20 \mathrm{ml}$ methanol for $72 \mathrm{hrs}$. The extract was concentrated under vacuum and dissolved in $5 \mathrm{ml}$ HPLC grade methanol. Standard solutions of swertiamarin (Day Natural), amarogentin (Day Natural) and mangiferin (Sigma) were prepared $(1 \mathrm{mg} / \mathrm{ml})$ separately. Working solutions of $100 \mu \mathrm{g} / \mathrm{ml}$ (i.e. $100 \mathrm{ng} / \mu \mathrm{l}$ ) were prepared from all the three standard solutions by diluting them with HPLC grade methanol. Chromatography was performed on $20 \mathrm{~cm} \times 10 \mathrm{~cm}$ pre-coated silica gel $60 \mathrm{~F}_{254}$ aluminium-backed TLC plates (Merck, Germany) of $0.25 \mathrm{~mm}$ layer thickness. A CAMAG HPTLC system (Muttenz, Switzerland) comprising a Linomat-5 automated sample applicator equipped with a $100 \mu \mathrm{l}$ syringe, CAMAG TLC scanner with winCATS software (version: 1.4.6), a UV cabinet and a twin-trough glass tank was used for the analysis. Details of the procedure of quantitative estimation have been described in previous communication (Samaddar et al. 2013). Four weeks old excised root cultures of S. chirayita (ScNTR), established on MS supplemented with $1.43 \mu \mathrm{M}$ IAA, were used as controls (since, unlike transformed roots, excised non-transformed roots do not grow on hormone free basal media). Three biological replicates $(n=15)$ were used and the experiment was repeated thrice.

Data were examined by a one-way analysis of variance (ANOVA) to detect significant differences ( $\mathrm{p} \leq 0.05)$ in the mean (Sokal and Rohlf 1987). Tukey's HSD test was performed for post-hoc analyses at the same $5 \%$ probability using SPSS software (version 16.0). Variability in the data was expressed as the mean \pm standard deviation (Sd).

\section{Results and Discussion}

In the present study, genetic transformation and induction of hairy roots with wild agropine strains of Agrobacterium rhizogenes was achieved in S. chirayita using whole micropropagated plants (Fig. 1). No hairy root induction was obtained from excised 
petiole and leaf lamina explants upon infection with any of the four strains. As the infection frequency depends directly on Agrobacterium strain, host genotype and explant physiology (Karami et al. 2009), A. rhizogenes strain and host explant selection become an

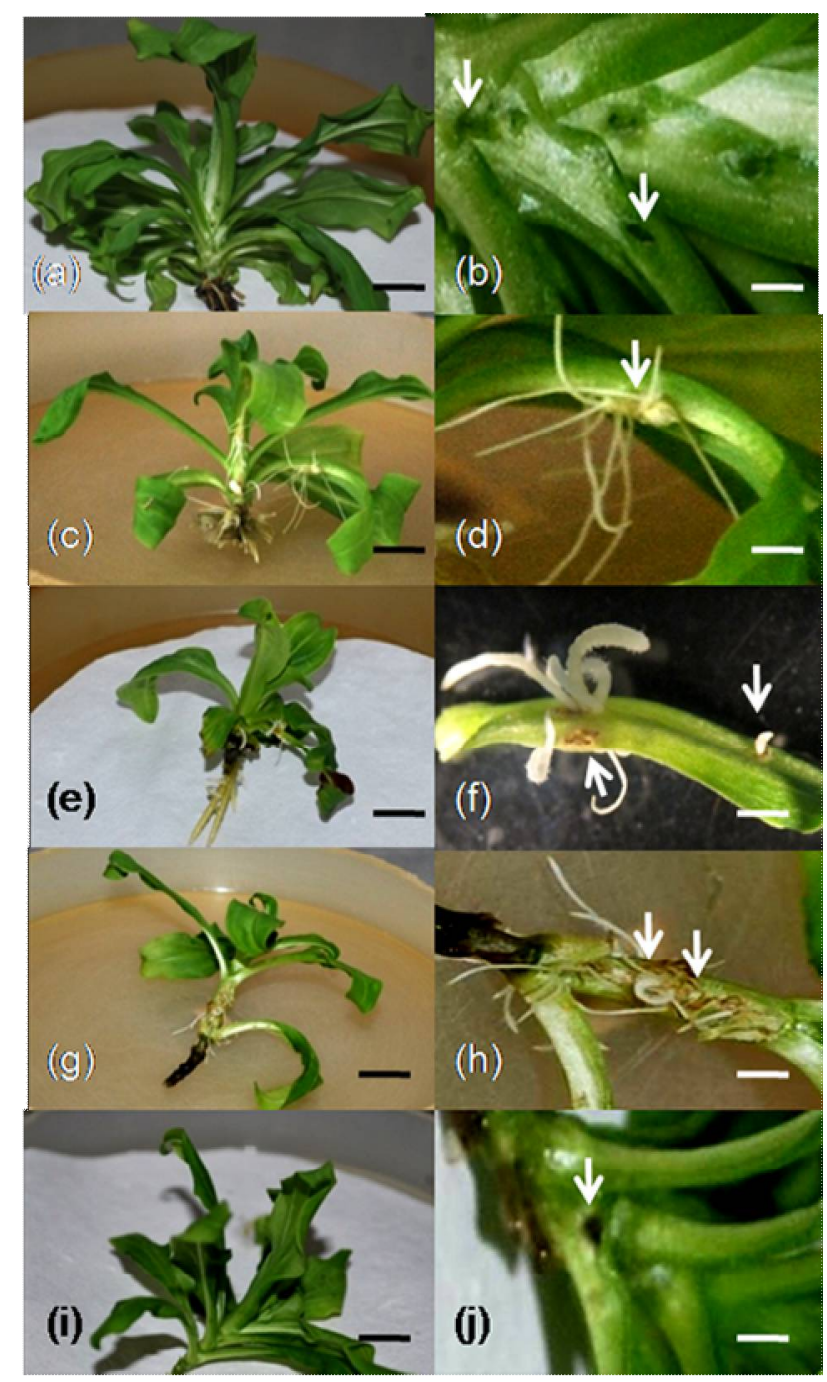

Fig. 1. Response of S. chirayita whole plants on A. rhizogenes infection $(\mathrm{a}, \mathrm{b})$ control explant showing no root induction, (c, d) explant infected with strain LBA9402, (e, f) infected with strain A4, (g, h) infected with strain HRI, $(i, j)$ infected with strain R1000. Arrows showing response at wound site. Bar $=1.65 \mathrm{~cm}$ (black) and $0.41 \mathrm{~cm}$ (white).

important factor for hairy root induction. Till date, there is one report where root induction from decapitated S. chirayita shoots upon infection with A. rhizogenes strains ATCC15834, LBA9402 and TR105 (Keil et al. 2000). Root induction was noticed from wound sites of petiole and node/internode regions of whole plants after 3 - 4 weeks. 
However, the frequency of root induction and the number of roots induced per wound site varied with infection sites and bacterial strains after 8 weeks of infection. Leaf lamina wound sites of whole plants did not show any rhizogenic response even after 8 weeks of infection with A. rhizogenes. Stem explants were also found to be more suitable for direct infection than leaf explants for hairy root induction in Gentiana cruciata (Hayta et al. 2011). It has been noted that leaf explants generally show a lower level of transformation rate in species belonging to family Gentianaceae (Mishiba et al. 2006, Tiwari et al. 2007), corroborating the present finding.

Whole plants of $S$. chirayita infected with A. rhizogenes strain LBA9402 at node/ internodal wound sites showed highest root induction frequency $(25 \pm 4.4 \%)$ with $2-9$ roots per wound site. The frequency of root induction from petiolar wound sites was 22.5 $\pm 4.2 \%$ with 1 - 9 roots induced per wound site. In case of $A$. rhizogenes strain A4, the frequency of root induction from node/internodal wound sites was significantly higher $(15 \pm 2.6 \%)$ than the frequency of root induction from petiolar wound sites $(10 \pm 1.2)$. The number of roots induced per node/internodal wound site ranged from 1 - 3 whereas the number of roots induced per petiolar wound site ranged from $1-6$. No significant differences were observed in root induction frequency from wound sites at node/internodal and petiolar regions when whole plants were infected with $A$. rhizogenes strain HRI. The number of roots induced per wound site ranged from 1-6 in case of node/internodal wound sites and 1 - 3 in case of petiole wound region. Explants inoculated with strain R1000 did not show any root induction even after 8 weeks of culture. Variable frequencies of infectivity by different strains of $A$. rhizogenes in a given species have been reported which may be due to the plasmids harbored by different bacterial strains (Mukherjee et al. 1995, Akramian et al. 2008). Till date, numerous strains of A. rhizogenes have been used for plant transformation (Bahramnejad et al. 2019). It is well-established that for optimizing protocol for developing hairy root culture lines in a species, selection of strain is required, as infectivity is species and strain dependent and as clarified by Thwe et al. (2016), has to be determined empirically.

Hairy roots induced by $A$. rhizogenes strain LBA9402 showed three-folds higher growth and developed many laterals within 4 weeks on $\mathrm{N} / 5$ medium as compared to MS and Gamborg's B5 media supplemented with ampicillin (500 $\mathrm{mg} /)$. Hence, N/5 medium supplemented with $500 \mathrm{mg} /$ ampicillin was used for the establishment of all Ritransformed root cultures in dark. Each primary root induced at the wound site was propagated as a separate root line (Roychowdhury et al. 2015). Keil et al. (2000) have reported that they were not successful in establishing transformed roots of $S$. chirayita on solid media, thus could not establish true hairy root lines. The concentration of nitrogen in the culture medium has been reported to affect the growth of hairy root cultures (Lourenco et al. 2002). In the present study, the Ri-transformed root lines of S. chirayita exhibited rapid, plagiotropic growth typical for Ri-transformed roots with long primary roots and numerous primary laterals, which very often gave rise to secondary laterals (Fig. 2a,b). Sixteen fast-growing axenic Ri-transformed root lines were selected (10 $9402-$ 
transformed root lines, 3 A4-transformed root lines and 3 HRI-transformed root lines) and maintained on $\mathrm{N} / 5$ medium by regular sub-culturing at 4 weeks interval for $1-2.5$ years in vitro. However, HRI-derived root lines were slow-growing as compared to other root lines and therefore were not considered for further studies. Excised non-transformed roots did not survive on any of the basal media and necrosed within 4 weeks of culture.

The selected Ri-transformed root lines showed variation in their morphology and growth (Table 1). Out of the ten 9402-transformed root lines, 8 showed lateral root density ranging from $1.28 \pm 0.07$ to $4.25 \pm 0.88$ per $\mathrm{cm}$ after 4 weeks. These root lines were relatively thick and yellowish white in color. Greenish white soft textured callus mass at branch points and tips of laterals were observed when these lines were kept for more than 8 weeks without sub-culturing. The remaining two lines i.e. Sc9402\#2 and Sc9402\#9 showed lateral densities significantly higher $(10.97 \pm 0.91$ and $7.45 \pm 0.44$ per $\mathrm{cm}$, respectively) which were thinner and white in color. Development of callus masses at branch points and tips of laterals were not observed in these two lines when kept without sub-culturing for more than 8 weeks. Three A4-transformed root lines (ScA4\#A, ScA4\#B, $\mathrm{ScA} 4 \#$ C) showed lateral densities ranging from $2.38 \pm 0.55$ to $2.75 \pm 0.66$ per $\mathrm{cm}$ and did not show any significant differences among them (Table 1). These root lines were morphologically thick and white in color that did not show any callusing at branch points and tips of laterals when kept without sub-culturing for more than 8 weeks. The root lines Sc9402\#2 and Sc9402\#14 showed significantly higher biomass accumulation (GI $=13.67 \pm 1.16$ and $12.5 \pm 2.36$, respectively).

PCR analysis revealed the integration of rolA, rolB, rolC and rolD genes of TL-DNA in all Ri-transformed root lines maintained in vitro for over three years (Fig. 3). The PCR products were of the expected size and were identical to those of the positive control for all of the genes studied. No amplification was observed with virD1 primers, used as control for false positive result of PCR. None of the primers produced any amplification when the genomic DNA of the non-transformed roots (negative control) was used as template DNA.

Spontaneous regeneration of shoot buds was observed in 60\% of 9402-transformed root lines (Sc9402\#2, Sc9402\#3, Sc9402\#5, Sc9402\#10, Sc9402\#11 and Sc9402\#14) when maintained in long-term culture (after 12 - 15 months of initiation of hairy root cultures) on N/5 medium in dark (Fig. 2c-f). Among them, Sc9402\#2, Sc9402\#5, Sc9402\#10 and Sc9402\#11 root lines showed direct shoot regeneration (Fig. 2e) whereas root lines Sc9402\#3 and Sc9402\#14 developed greenish white or yellow tiny callus masses at branch points prior to shoot bud induction (Fig. 2f). Highest number of shoot buds $(\sim 3-4$ plantlets per petriplate) was observed in root line Sc9402\#11 when kept without subculturing for more than 8 weeks. No spontaneous regeneration of shoot buds directly or indirectly was observed in A4 and HRI-transformed root cultures. Direct as well as indirect development of adventitious shoot buds from hairy root cultures in hormonefree media have been reported earlier in many plant species and reviewed (Brillanceae 
et al. 1989, Lee et al. 2004, Chaudhuri et al. 2006, Gangopadhyay et al. 2010, Majumdar et al 2011, Sarkar et al. 2018). PCR analysis revealed the integration of rolA, rolB, rolC and
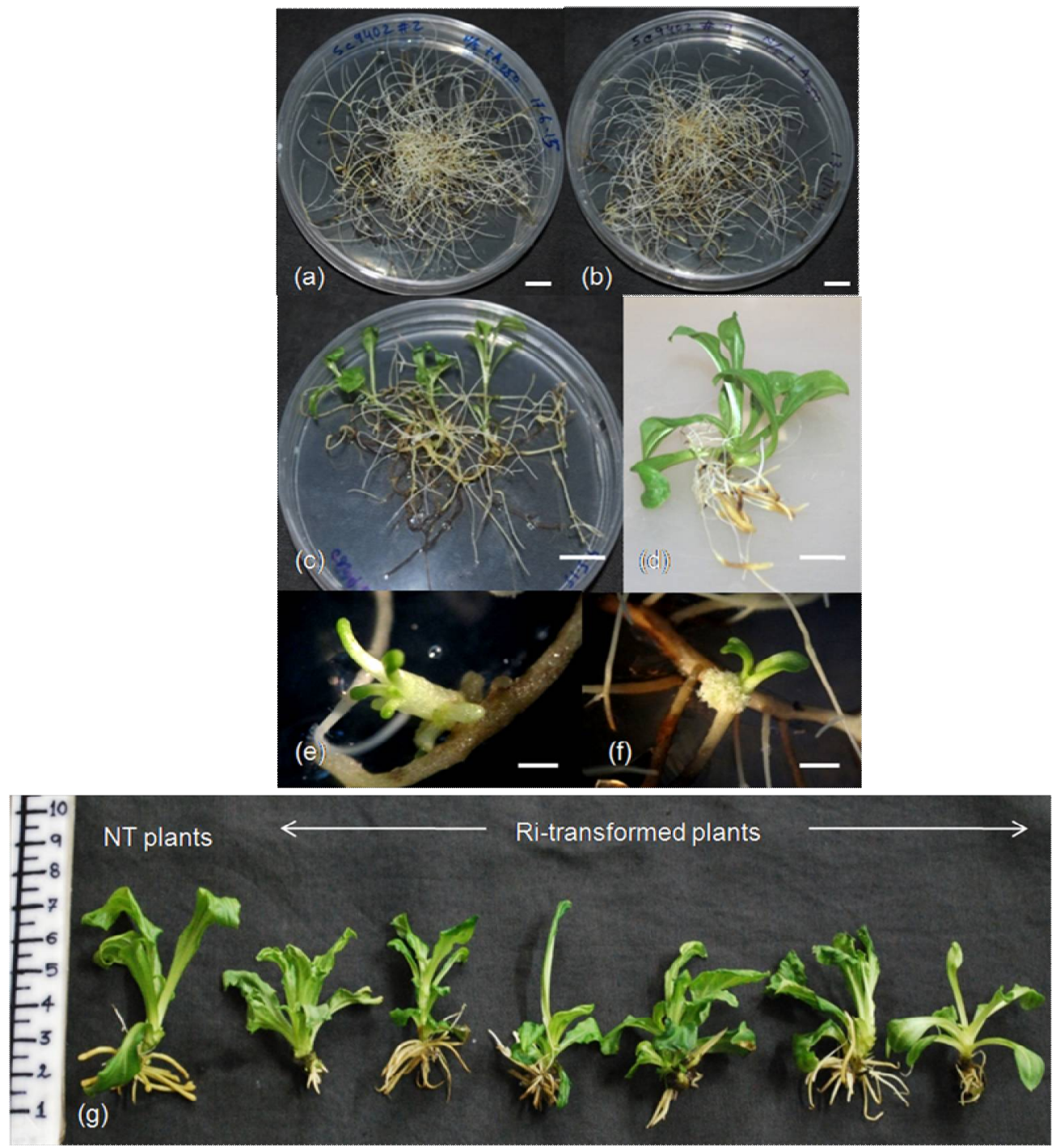

Fig. 2a,b. Ri-transformed root lines showing high lateral root density and biomass accumulation $(B a r=1.13 \mathrm{~cm})$. (c) Spontaneous shoot regeneration from Ri-transformed root culture $(B a r=1.44 \mathrm{~cm})$. (d) Regenerated plantlet $(B a r=1.00 \mathrm{~cm})$. (e) Direct shoot regeneration $(B a r=0.40 \mathrm{~cm})$. (f) Shoot regeneration preceded by callus induction $(\mathrm{Bar}=0.40 \mathrm{~cm})$. $(\mathrm{g})$ Non-transformed and different Ri-transformed plant lines of $S$. chirayita.

rolD genes of TL-DNA in all Ri-transformed plant lines (Fig. 4) of S. chirayita after 12 months of maintenance in vitro on MS. The PCR amplicons were of expected size and were identical to those of the positive controls. None of the primers produced any 
amplification when genomic DNA from non-transformed plants was used. No amplification for virD1 gene was observed in any Ri-transformed plant lines which eliminates the possibility of bacterial contamination.

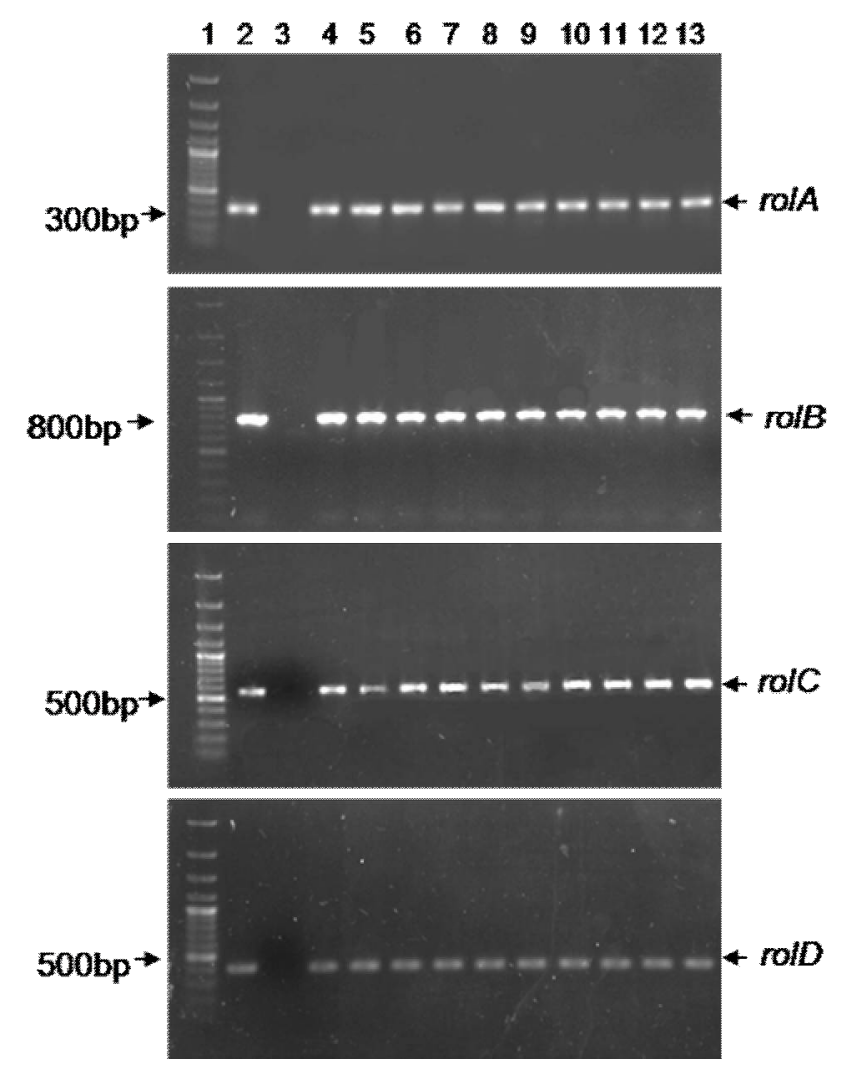

Fig. 3. Integration of Ri T-DNA genes in Ri-transformed root lines by PCR analysis using rolA, rolB, rolC and rolD primers. Lane 1: molecular marker (1000 bp plus DNA ladder), lane 2: positive control (pLJ1), lane 3: negative control (genomic DNA of non-transformed roots), lanes 4-10: 9402-transformed root lines, lanes 1113: A4-transformed root lines.

HPTLC analysis revealed the presence of swertiamarin in 9402-transformed root lines. The content of swertiamarin (Table 1) ranged between $0.042 \pm 0.004 \%$ (root line Sc9402\#10) and $0.207 \pm 0.004 \%$ (root line Sc9402\#3). Amarogentin was detected in root lines Sc9402\#3 $(0.019 \%)$ and Sc9402\#11 (0.012\%) whereas mangiferin was detected only in root line Sc9402\#14 (0.017\%). However, swertiamarin, amarogentin and mangiferin could not be detected in any of A4-transformed root lines (ScA4\#A, ScA4\#B and ScA4\#C) as well as excised non-transformed root cultures of $S$. chirayita grown on auxin supplemented medium. Variability in morphology, growth and metabolite productivity among transformed root clones has been reported earlier in several plant species like Arachis 
hypogea (Halder and Jha 2016), Tylophora indica (Chaudhuri et al. 2005), Catharanthus roseus (Batra et al. 2004) and Rauvolfia serpentina (Ray et al. 2014).

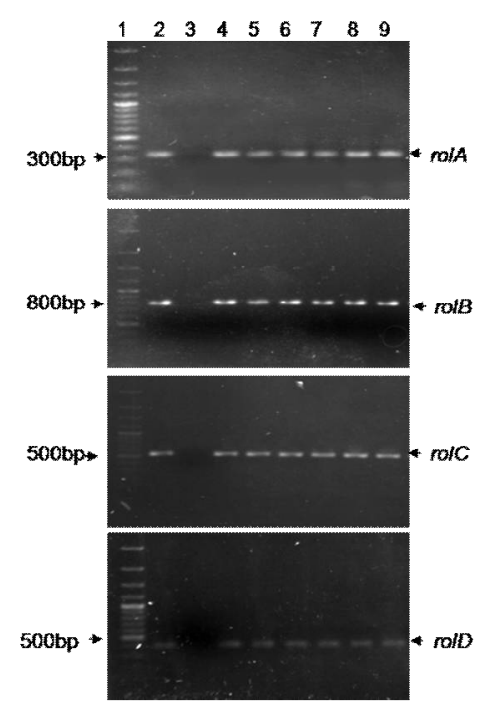

Fig. 4. Integration of Ri T-DNA genes in Ri-transformed plant lines by PCR analysis using rolA, rolB, rolC and rolD primers. Lane 1: molecular marker (1000 bp plus DNA ladder), lane 2: positive control (pLJ1), lane 3: negative control (genomic DNA of non-transformed leaves), lanes 4-9: Six Ri-transformed plant lines.

Table 1. Growth and swertiamerin content in nine Ri-transformed root lines of S. chirayita after 4 weeks of culture on solid N/5 medium $(n=45)$.

\begin{tabular}{llll}
\hline $\begin{array}{l}\text { Ri-transformed root } \\
\text { lines of } \text { S. chirata }\end{array}$ & $\begin{array}{l}\text { Lateral density } \\
(\text { per cm) }\end{array}$ & $\begin{array}{l}\text { Growth index } \\
(\text { FW })\end{array}$ & $\begin{array}{l}\text { \% of swertiamarin } \\
(\text { mean } \pm \text { SE) }\end{array}$ \\
\hline Sc9402\#2 & $10.97 \pm 0.91^{\mathrm{d}}$ & $13.67 \pm 1.16^{\mathrm{e}}$ & $0.088 \pm 0.003^{\mathrm{b}}$ \\
Sc9402\#9 & $7.45 \pm 0.44^{\mathrm{c}}$ & $10.70 \pm 0.63^{\mathrm{cd}}$ & $0.083 \pm 0.001^{\mathrm{b}}$ \\
Sc9402\#14 & $1.28 \pm 0.07^{\mathrm{a}}$ & $12.50 \pm 2.36^{\mathrm{de}}$ & $0.102 \pm 0.002^{\mathrm{b}}$ \\
Sc9402\#11 & $2.37 \pm 0.75^{\mathrm{a}}$ & $8.57 \pm 0.40^{\mathrm{bc}}$ & $0.177 \pm 0.025^{\mathrm{cd}}$ \\
Sc9402\#12 & $4.25 \pm 0.88^{\mathrm{b}}$ & $6.70 \pm 0.17^{\mathrm{ab}}$ & $0.087 \pm 0.013^{\mathrm{b}}$ \\
Sc9402\#15 & $2.89 \pm 0.85^{\mathrm{ab}}$ & $6.15 \pm 0.15^{\mathrm{ab}}$ & $0.183 \pm 0.023^{\mathrm{de}}$ \\
Sc9402\#10 & $2.41 \pm 0.34^{\mathrm{a}}$ & $6.13 \pm 0.19^{\mathrm{ab}}$ & $0.042 \pm 0.004^{\mathrm{a}}$ \\
Sc9402\#5 & $1.33 \pm 0.03^{\mathrm{a}}$ & $4.70 \pm 0.40^{\mathrm{a}}$ & $0.147 \pm 0.003^{\mathrm{c}}$ \\
Sc9402\#3 & $1.51 \pm 0.38^{\mathrm{a}}$ & $4.03 \pm 1.01^{\mathrm{a}}$ & $0.207 \pm 0.004^{\mathrm{e}}$ \\
\hline
\end{tabular}

Values represent mean $\pm \mathrm{Sd}$. Means with same letter are not significantly different according to Tukey's HSD test $(\mathrm{p} \leq 0.05)$. 
The rol genes of T-DNA have been reported to affect the secondary metabolite accumulation in hairy roots, Ri-transformed callus and Ri transformed plants in large number of taxonomically diverse plant species (Palazón et al. 1998, Bonhomme et al. 2000, Bulgakov 2008, Bulgakov et al. 2011). However, how the rol genes of A. rhizogenes induce the various diverse synthesis of secondary metabolites is not known (Hakkinen et al. 2016). Ri-transformed plants spontaneously regenerated from hairy roots showed enhanced accumulation of swertiamerin and amarogentin as compared to nontransformed plants of similar age. The content of swertiamerin was enhanced four-fold $(1.15 \pm 0.021 \%)$ and that of mangiferin was enhanced two-folds $(0.51 \pm 0.01 \%)$ over nontransformed control shoot cultures.

The enhanced production of the swertiamerin (secoiridoid) in hairy root cultures and Ri-transformed plants in the critically endangered species S. chirayita, which will be helpful in optimizing alternate methodologies for production of the active principles of the species and thus help in preventing its destruction from the wild. Further work is needed to manipulate culture conditions, to optimize productivity and content of secondary metabolites in hairy root culture of this species as carried out in large number of other species for improvement in production of secondary metabolites in hairy root cultures (Halder et al. 2019).

\section{Acknowledgements}

The first author (TS) gratefully acknowledges University Grants Commission, New Delhi, for the award of Research Fellowship for Meritorious Students for completion of her PhD thesis. Authors thank the Head Department of Botany and the Programme Coordinator, CAS in Botany, University of Calcutta for providing the research facilities.

\section{References}

Akramian M, Tabatabaei SMF and Mirmasoumi M (2008) Virulence of different strains of Agrobacterium rhizogenes on genetic transformation of four Hyoscyamus species. Am. Eurasian J. Agric. Environ. Sci. 3: 759-763.

Alpizar E, Dechamp E, Lapeyre-Montes F, Guilhaumon C, Bertrand B, Jourdan C, Lashermes $\mathbf{P}$ and Etienne $\mathbf{H}$ (2008) Agrobacterium rhizogenes transformed roots of Coffee (Coffea arabica): conditions for long-term proliferation and morphological and molecular characterization. Ann. Bot. 101: 929-940.

Bahramnejad B, Naji M, Bose R and Jha S (2019) A critical review on use of Agrobacterium rhizogenes and their associated binary vectors for plant transformation. Biotechnol. Adv. https://doi.org/10.1016/.biotechadv.2019.06.004.

Batra J, Dutta A, Singh D, Kumar S and Sen J (2004) Growth and terpenoid indole alkaloid production in Catharanthus roseus hairy root clones in relation to left- and right-termini-linked Ri T-DNA gene integration. Plant Cell Rep. 23: 148-154. 
Bonhomme V, Laurain-Mattar D and Fliniaux MA (2000) Effects of the rolC gene on hairy root: Induction, development and tropane alkaloid production by Atropa belladonna. J. Nat. Prod. 63: 1249-1252.

Brahmachari G, Mondal S, Gangopadhyay A, Gorai D, Mukhopadhyay B, Saha S and Brahmachari A (2004) Swertia (Gentianaceae): Chemical and pharmacological aspects. Chem. Biodivers 1: 1627-1651.

Brillanceau MH, David C and Tempé J (1989) Genetic transformation of Catharanthus roseus G. Don by Agrobacterium rhizogenes. Plant Cell Rep. 8: 63-66.

Bulgakov VP (2008) Functions of rol genes in plant secondary metabolism. Biotechnol. Adv. 26: 318-324.

Bulgakov VP, Shkryl YN, Veremeichik GN, Gorpenchenko TY and Inyushkina YV (2011) Application of Agrobacterium rol genes in plant biotechnology: A natural phenomenon of secondary metabolism regulation. In: Genetic transformation, Alvarez M (Ed.), InTech, Rijeka, pp. 261-271.

Chaudhuri KN, Ghosh B, Tepfer D and Jha S (2005) Genetic transformation of Tylophora indica with Agrobacterium rhizogenes A4: Growth and tylophorine productivity in different transformed root clones. Plant Cell Rep. 24: 25-35.

Chaudhuri KN, Ghosh B, Tepfer D and Jha S (2006) Spontaneous plant regeneration in transformed roots and calli from Tylophora indica: Changes in morphological phenotype and tylophorine accumulation associated with transformation by Agrobacterium rhizogenes. Plant Cell Rep. 25: 1059-1066.

Gamborg OL, Miller RA and Ojima K (1968) Nutrient requirements of suspension cultures of soybean root cells. Expt. Cell Res. 50: 151-158.

Gangopadhyay M, Chakraborty D, Bhattacharyya S and Bhattacharya S (2010) Regeneration of transformed plants from hairy roots of Plumbago indica. Plant Cell Tiss. Org. Cult. 102: 109114.

Häkkinen ST, Moyano E, Rosa M, Cusidó RM and Oksman-Caldentey KM (2016) Exploring the metabolic stability of engineered hairy roots after 16 years maintenance. Front Plant Sci. 7: 1486.

Halder M and Jha S (2016) Enhanced trans-resveratrol production in genetically transformed root cultures of peanut (Arachis hypogaea L.). Plant Cell Tiss. Org. Cult. 124: 555-572.

Halder M, Roychowdhury D and Jha S (2018) A critical review on biotechnological interventions for production and yield enhancement of secondary metabolites in hairy root cultures. In: Hairy Roots, Srivastava V, Mehrotra S and Mishra S (Eds.), Springer, Singapore, pp. 21-44.

Halder M, Sarkar S and Jha S (2019) Elicitation: A biotechnological tool for enhanced production of secondary metabolites in hairy root cultures. Engineering in Life Sciences 1-16. DOI: 10.1002/elsc. 201900058

Hayta S, Gurel A, Akgun IH, Altan F, Ganzera M, Tanyolac B and Bedir E (2011) Induction of Gentiana cruciata hairy roots and their secondary metabolites. Biologia 66: 618-625.

Hooykaas PJ, Klapwjik PM, Nuit MP, Schilperoot RA and Hirsch A (1977) Transfer of the $A$. tumefaciens Ti plasmid to avirulent Agrobacteria and Rhizobium ex planta. J. Gen. Microbiol. 98: 477-484.

Joshi P and Dhawan V (2005) Swertia chirayita - An overview. Curr. Sci. 89: 635-640. 
Agrobacterium rhizogenes Mediated Transformation

Karami O, Esna-Ashari M, Kurdistani GK and Aghavaisi B (2009) Agrobacterium-mediated genetic transformation of plants: The role of host. Biol. Plantarum 53: 201-212.

Keil M, Hartle B, Guillaume A and Psiorz M (2000) Production of amarogentin in root cultures of Swertia chirata. Planta Med. 66: 452-457.

Kirtikar KR and Basu BD (1984) Indian Medicinal Plants, Vol III. LM Basu Publishers, Allahabad.

Kumar V and Staden JV (2016) A review of Swertia chirayita (Gentianaceae) as a traditional medicinal plant. Front. Pharmacol. 6: 308.

Lee MH, Yoon ES, Jeong JH and Choi YE (2004) Agrobacterium rhizogenes-mediated transformation of Taraxacum platycarpum and changes of morphological characters. Plant Cell Rep. 22: 822-827.

Lourenco PML, Castro SD, Martins TM and Domingos AC (2002) Growth and proteolytic activity of hairy roots from Centaurea calcitrapa: Effect of nitrogen and sucrose. Enzyme Microb. Technol. 31: 242-249.

Majumdar S, Garai S and Jha S (2011) Genetic transformation of Bacopa monnieri by wild type strains of Agrobacterium rhizogenes stimulates production of bacopasaponins in transformed calli and plants. Plant Cell Rep. 30: 941-954.

Mishiba K, Nishihara M, Abe Y, Nakatsu T, Kawamura H, Kodama K, Takesawa T and Abe J (2006) Production of dwarf potted gentian using wild-type Agrobacterium rhizogenes. Plant Biotechnol. 23: 33-38.

Mukherjee S, Ghosh B, Jha TB and Jha S (1995) Genetic transformation of Artemisia annua by Agrobacterium rhizogenes. Indian J. Expt. Biol. 33: 868-871.

Palazón J, Cusidó RM, Roig C and Pinol MT (1998) Expression of the rolC gene and nicotine production in transgenic roots and their regenerated plants. Plant Cell Rep. 17: 384-390.

Pant N, Jain DC and Bhakuni RS (2000) Phytochemicals from genus Swertia and their biological activities. Indian J. Chem. 39: 565-586.

Petit A, David C, Dahl G, Ellis J, Guyon P, Casse-Delbart F and Tempe' J (1983) Further extension of the opine concepts: plasmids in Agrobacterium rhizogenes cooperate for opine degradation. Mol. Gen. Genet. 207: 245-250.

Ray S, Majumder A, Bandyopadhyay M and Jha S (2014) Genetic transformation of sarpagandha (Rauvolfia serpentina) with Agrobacterium rhizogenes for identification of high alkaloid yielding lines. Acta Physiol. Plant. 36: 1599-1605.

Roychowdhury D, Basu A and Jha S (2015) Morphological and molecular variation in Ritransformed root lines are stable in long term cultures of Tylophora indica. Plant Growth Regul. 75: 443-453.

Samaddar T, Chaubey B, Jha S and Jha TB (2013) Determination of swertiamarin and amarogentin content and evaluation of antibacterial activity in Eastern Himalayan species of Swertia L. Pharmacogn. Commun. 3: 64-70.

Samaddar T, Jha S and Jha TB (2014) Indian Swertia from Eastern Himalaya: Strategies of conservation and biotechnological improvements. In: The Gentianaceae - Volume 1: Characterization and Ecology, Rybczinski J, Davey M and Mikula A (Eds.), Springer, Berlin, Heidelberg, pp. 279-301.

Sambrook J and Russel DW (2001) Molecular cloning: A laboratory manual, 3rd edn. Cold Spring Harbour Press, Cold Spring Harbour, New York. 
Sarkar S, Ghosh I, Roychowdhury D and Jha S (2018) The effects of rol genes of Agrobacterium rhizogenes on morphogenesis and secondary metabolite accumulation in medicinal plants. In: Biotechnological Approaches for Medicinal and Aromatic Plants, Kumar N (Ed.), Springer, Singapore, pp. 27-51.

Sokal RR and Rohlf FJ (1987) Introduction to biostatistics. WH Freeman \& Co., New York.

Tepfer D (1995) Agrobacterium rhizogenes mediated transformation: Transformed roots to transformed plants. In: Gene transfer to plants, Potryukus I (Ed.), Springer-Verlag, Berlin, pp. 45-52.

Thwe A, Arasu MV, Li X, Park CH, Kim SJ, Al-Dhabi NA and Park SU (2016) Effect of different Agrobacterium rhizogenes strains on hairy root induction and phenylpropanoid biosynthesis in tartary buckwheat (Fagopyrum tataricum Gaertn). Front. Microbiol. 7: 318.

Tiwari RK, Trivedi M, Guang ZC, Guo G and Zheng G (2007) Genetic transformation of Gentiana macrophylla with Agrobacterium rhizogenes: Growth and production of secoiridoid glucoside gentiaopicroside in transformed hairy root cultures. Plant Cell Rep. 26: 199-210.

Vervliet G, Holsters M, Teuchy H, Van Montagut M and Schell J (I975) Characterization of different plaque-forming and defective temperate phages in Agrobacterium strains. J. Gen. Virol. 26: 33-48.

Zhou NJ, Geng CA, Huang XY, Ma YB, Zhang XM, Wang JL and Chen JJ (2015) Anti-hepatitis B virus active constituents from Swertia chirayita. Fitoterapia 100: 27-34.

(Manuscript received on 03 September, 2019; revised on 14 October, 2019) 